\title{
A STUDY ON MODES OF COMMUNICATION IN CASES OF SEXUAL ASSAULT
}

\author{
Vadysinghe $\mathrm{AN}^{1}$, Senasinghe, $\mathrm{DPP}^{2}$, Attygalle $\mathrm{U}^{3}$, Ilangarathna Banda $\mathrm{YMG}^{4}$, \\ Ramanayake $\mathbf{R S}^{\mathbf{1}}$ \\ ${ }^{I}$ Department of Forensic Medicine, Faculty of Medicine, University of Peradeniya, \\ General Hospitals $-{ }^{2}$ Nawalapitiya, ${ }^{3}$ Rathnapura $\&{ }^{4}$ Chilaw
}

\section{INTRODUCTION}

The Sexual assaults which have shown an alarming rise are a serious public health problem with hazardous socioeconomic and health related consequences around the globe ${ }^{1}$ (eg:Teenage pregnancy, STI, Abortion, Suicide). This applies to Sri Lanka as well.

Sri Lanka Police Bureau, "Grave Crime Abstract of the $1^{\text {st }}$ quarter of 2012" shows that 458 - rape/incests, 121 - un natural offences/grave sex abuse, 376 - has been reported to them from all over the country ${ }^{2}$.

With the growing advances in the technology in the near past, cell phone ownership had become ubiquitous among teens and young adults. ${ }^{3}$ The Central Bank Annual report of 2012, states that the number of mobile phone connections has increased to 20.3 million in Sri Lanka. ${ }^{4}$ As people increasingly use social networking services and mobile phone technologies to communicate and socialise with each other, their use as vehicles for the perpetration of sexual assault is becoming an issue of significant concern for those working in the sexual assault field (Powell, 2009) and is the subject of growing media debate. This concern relates partly to the way in which such technology multiplies avenues for sexual victimisation. It also relates to a lack of understanding among some groups about how these technologies work, what exactly the nature of the problem is and what solutions are required to address perpetration and its impacts $^{5,6}$.

A number of cases have been recently reported in which mobile phone and online communication technologies have been connected to sexual assault victimisation, and there are hardly any research done in Sri Lanka about this issue. Therefore this study is carried out about the modes of communication between the victims and the assailants in our country.

\section{OBJECTIVES}

The objective of the study is to determine the modes of communication used between the assailants and the victims in cases of sexual assault.

\section{METHODOLOGY}

This study was conducted on the sexually assaulted individuals who were brought to the hospitals in Central, Sabaragamuwa and North Western provinces for medico-legal examination during the period of December 2011 and June 2012.

This is a descriptive cross sectional study and the data was obtained from sexually assaulted females and males using a standard questionnaire by specialists and trainees in Forensic Medicine, maintaining the professional standards. Data was analysed using Microsoft Excel software.

\section{RESULTS}

Among 62 sexually assaulted victims, $96 \%$ were females. $81 \%$ of them were less than 18 years of age and among them, $43 \%$ were in 12-16 years age group, $15 \%$ were aged below 10 years with $3.2 \%$ being below 5 yrs. Only $19.3 \%$ of the victims were more than 19years old [See Table $1]$. 
Table 01: Age distribution of the victims

\begin{tabular}{|l|l|l|l|l|l|l|l|l|}
\hline Age & $0-5$ & $6-9$ & $10-12$ & $13-14$ & $15-16$ & $17-18$ & $>19$ & Total \\
\hline$\%$ & 3.2 & 12.9 & 3.2 & 19.3 & 32.2 & 9.6 & 19.3 & 100 \\
\hline
\end{tabular}

Table 02: Monthly income range of the victims

\begin{tabular}{|l|l|}
\hline $\begin{array}{l}\text { Income range (Rupees) / } \\
\text { Month }\end{array}$ & Percentage \\
\hline $0-5000$ & 16.1 \\
\hline $5000-10000$ & 6.4 \\
\hline $10000-15000$ & 35.5 \\
\hline $15000-20000$ & 16.1 \\
\hline $20000-25000$ & 12.9 \\
\hline $25000-30000$ & 0.0 \\
\hline $30000-35000$ & 6.4 \\
\hline $35000-40000$ & 6.4 \\
\hline
\end{tabular}

Regarding the monthly income of the victims/families $74.3 \%$ had a monthly income of less than Rs. 20,000, $21.5 \%$ less than Rs. 10000 with $16 \%$ earning less than Rs.5000 and only $12.8 \%$ has a monthly income more than Rs.25000 [See Table 2]

$1 U S D=R s .126 .7$

\section{Methods of Communication}

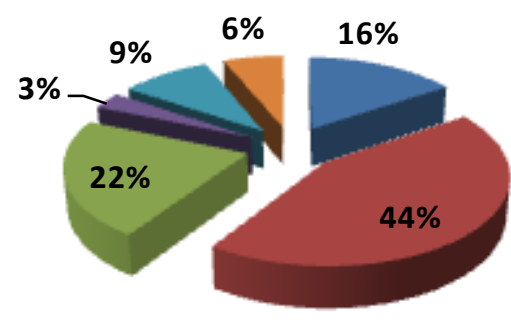

Mobile (MB)

Direct Verbal (DV)

$\mathrm{MB}+\mathrm{DV}$

Letters (L)

$M B+D V+L$

Others

Verbal communication was the commonest method of communication $(44 \%)$ in which $88 \%$ have spoken directly with the assailant, followed by mobile phone and direct verbal $(22 \%)$ and mobile phone only (16\%). $3 \%$ had communicated with letters. $9 \%$ had communicated with letters, mobile phones, and verbally. However, the mobile phone usage could be seen in $47 \%$ of cases [See Fig.01].

Figure 01

Table 04 : Methods used in mobile phone communication

\begin{tabular}{|l|c|}
\hline $\begin{array}{l}\text { Method of } \\
\text { communication }\end{array}$ & Percentage \\
\hline SMS & - \\
\hline TALK & $27 \%$ \\
\hline MMS & \\
\hline SMS+TALK & $73 \%$ \\
\hline
\end{tabular}

When considering the methods victims used to communicate with the assailant $27 \%$ had talked over the phone and $73 \%$ have uses SMS (Short Message service) along with speaking over the phone. However there were none who used only SMS as the mode of communication. MMS (Multimedia Message Service) was not found to be used by any of the victims. 


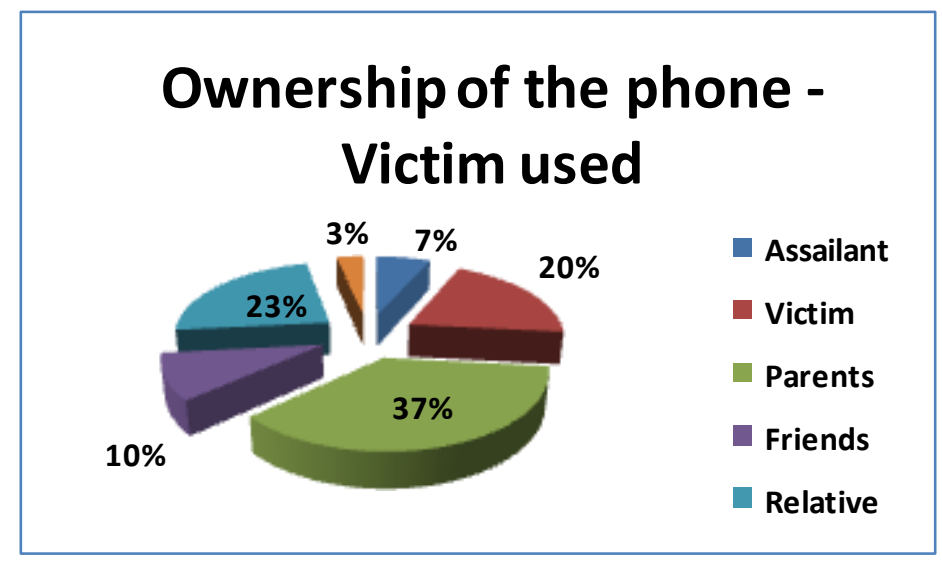

Figure 02

\section{Type of Connection / package}

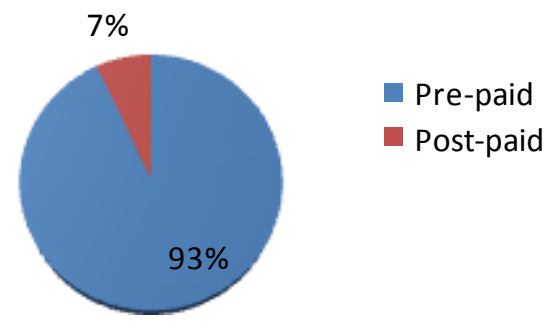

Figure 03

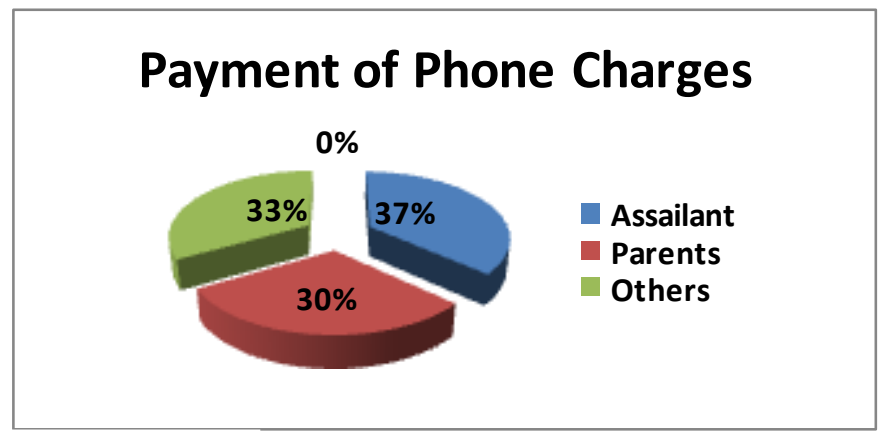

Figure 04

In single episodes of sexual assault, in $80 \%$ of cases direct verbal communication was seen with $10 \%$ showing the use of a mobile phone also. In single episodes there were no victims who used a mobile phone only for communication. In multiple episodes $63 \%$ of victims had used a mobile phone with only $29 \%$ having had direct verbal communication only [See Table 03].
$20 \%$ of the victims used their own mobile phones, $80 \%$ used mobile phones owned by others to communicate with the assailant. $37 \%$ had used their parents phones followed by $23 \%$ who used their relatives phones, $10 \%$ had used their friends phones. Only $7 \%$ had used a mobile phone which was owned by the assailant. [See Fig. 02].

93\% of the phones used had prepaid connections, where as $7 \%$ had post-paid connections [See Fig. 03].
$37 \%$ of the time the payments had been settled by the accused and $30 \%$ of the time by the parents. [See Fig. 04]. 
Table 03: Frequency of sexual assault vs. Methods of Communication

\begin{tabular}{|c|c|c|c|c|c|}
\hline \multirow{2}{*}{$\begin{array}{c}\text { Number of } \\
\text { sexual assault }\end{array}$} & \multirow{2}{*}{$\begin{array}{c}\text { Number } \\
\text { of victims }\end{array}$} & \multicolumn{4}{|c|}{ Methods of communication } \\
\cline { 3 - 6 } & & Direct verbal & Mobile & $\begin{array}{c}\text { Mobile + direct } \\
\text { verbal }\end{array}$ & Others \\
\hline Single & 20 & $70 \%$ & $0 \%$ & $10 \%$ & $20 \%$ \\
\hline Multiple & 42 & $29 \%$ & $37 \%$ & $26 \%$ & $08 \%$ \\
\hline
\end{tabular}

\section{DISCUSSION}

The prevalence of unwanted sexual interaction, sexual violence and sexual abuse among young people is increasing rapidly throughout the world and specially so in developing countries like ours. Young people, particularly young women, comprise an "at-risk" demographic in relation to sexual violence. ${ }^{7}$ Studies have revealed that for both males and females, in a majority of cases the perpetrator and the victim knew each other. ${ }^{8}$

It is known that the ever-increasing use of communication technologies such as the Internet (particularly online social networking sites) and mobile phones in the commission or promotion of sexual assault has emerged as a challenging issue for support services, criminal justice agencies, and - with the ubiquity of technology in young people's lives - schools, educators and parents. ${ }^{9}$

It has been reported in many studies that most of the sexually assaulted victims were females and our study sample also consisted of $96 \%$ of females. $^{10,11,12,13}$ A majority of them were less than 18 years. It has been reported in the literature that the victims were usually in their teens. $^{8,10,12,14,15,16}$ In our study group $71.63 \%$ of the victims were from low socioeconomic group. Ganguly et $\mathrm{al}^{17}$ reported $60 \%$ of the victims were from poor families and $43 \%$ were illiterate. Similar findings were observed by Sarkar et al. ${ }^{8}$

When considering the communication methods, verbal communication was the commonest method used which included direct verbal and also verbal communication via a mobile phone.
Short messages and letters were also used by a minority. Altogether mobile phone usage could be seen in $47 \%$ of cases. The methods victims used to communicate with the assailant using the mobile phones showed that, $27 \%$ had talked over the phone and $73 \%$ have used SMS along with speaking over the phone. However there were none who used only SMS as the mode of communication. $20 \%$ of the victims used their own mobile phones, $80 \%$ used mobile phones owned by others to communicate with the assailant. $37 \%$ of the time the payments had been settled by the accused and $30 \%$ of the time by the parents. $93 \%$ of the connections of the mobile phones had pre-paid packages and only 7 $\%$ had post-paid ones. As post- paid packages usually provide the customers with a detailed bill it is likely that the assailants preferred to use the pre- paid connections which would not leave evidence of the details of use of the phone, for the parents of the victims or any other party to see. In single episodes of sexual assaults, in the majority of cases direct verbal communication was seen with only a minority showing mobile phone usage which was vice versa when it came to multiple episodes of sexual assaults.

In this study we did not come across any who had used social networking sites as a mode of communication. But with the developing technology, smart phones, tabs etc which have easy access to the internet are being commonly and increasingly used by the youth in our country. ${ }^{18}$ This has led to social networking sites become part of the everyday activities of the young. Therefore we should be vigilant to 
the dangers of those and an increase in the number of sexual assaults can be expected.

Educating parents as well as young adults about the possibility of sexual assaults and other serious consequences of using mobile phones and when using social networking sites to contact strangers and coming up with certain age restrictions for the use of those would help in reducing the number of sexual assaults among young individuals. At the same time health education targeted on vulnerable groups regarding sexual behaviour, legal aspects of sexual and partner relationship in an organized system is important for primary prevention of sexual assaults.

\section{SUGGESTIONS}

It appears that the unhindered access to mobile phones by the young individuals and technological advancements in the mobile telephony had facilitated the commission of sexual offences. The parents and guardians should be extra vigilant about the unfettered usage of mobile phones by the youth.

\section{REFERENCES}

1. Resurgence, The Prevalence of Sexual Assault, Justin and Lindsey Holcomb

2. Grave Crime abstract for the $1^{\text {st }}$ quarter of the year 2012 of the Sri Lanka Police.

3. Lenhart, A, Purcell, K, Smith, A., \& Zickuhr, K. Social media and mobile Internet use among teens and young adults. Washington, DC: Pew Research Centre, 2010

4. The Central Bank Annual report of 2012

5. Australian institute of family studies, Australian center for the study of sexual abuse http://www.aifs.gov.au/acssa/pubs/newsletter/n2 5/n25-2.html

6. Choo, K. K. R.. Online child grooming: $A$ literature review on the misuse of social networking sites for grooming children for sexual offences Canberra: Australian Institute of Criminology, 2009

7. Colombage SM, Dassanayaka PB, Waidyaratne DL, A study on child abuse in Anuradhapura, Colombo South and Ratnapura. 2005.

8. Sarkar SC, Lalwani S, Rautji R, Bhardwaj DN, Dogra TD. A Study on Victims of Sexual Offences in South Delhi, Dept of Forensic
Medicine and Toxicology, AIMS, New Delhi, India, 2010; 1-6.

9. Couts, R., \& Selby, H. Safe and unsafe use of mobile phone evidence. Paper presented at Public Defenders Criminal Law Conference, 2009

10. Kathleen C. Basile and Sharon G. Sexual Violence Victimization of Women: Prevalence, Characteristics, and the Role of Public Health and Prevention. Smith American Journal of Lifestyle Medicine 2011; 5: 407

11. Hwa HL, Chen SC, Wu M, Shun CT, Liu SK, Lee JC, Chn YC. Analysis of cases of sexual assault presenting at a medical center in Yaipei Taiwan J ObstetGynecol, 2010; 49(2):165- 169.

12. $\mathrm{Wu} \mathrm{ZH}$, Berenson $\mathrm{AB}$, Wieman CM. A profile of adolescent females with a history of sexual assault in Texas: familial environment, risk behaviors and health status. J PediatrAdolescGynecol 2003; 16:207-216.

13. Ingemann-Hansen $\mathrm{O}$, Sabroe $\mathrm{S}$, Brink $\mathrm{O}$, Mpsych MK, Charles AV. Characteristics of victims and assaults of sexual violenceimproving inquires and prevention. Journal of forensic and legal medicine 2009; 16:182-188.

14. Kilpatrick DG, Edmunds CN, Seymour AK. Rape in America: A Report to the Nation. Arlington, VA: National Victim Center \& Medical University of South Carolina, 1992.

15. Basile KC, Chen J, Black MC, Saltzman LE. Prevalence and characteristics of sexual violence victimization among U.S. adults 20012003.Violence Vict. 2007;22:437-448.

16. Brener CD, McMahon PM, Warren CW, Douglas KA. Forced sexual intercourse and associated health-risk behaviors among female college students in the United States. J Consult Clin Psychol. 1999; 67:252-259.

17. Ganguly RP, Patron KK, Jha T, Bhattacharya AR, Sarkar D. Sexual assault and its medical, Medico-legal and Social aspects-a retrospective study. J Indian Med Assoc. 2010; 108(10): 68290.

18. Boyd, D. Why youth (heart) social network sites: The role of networked publics in teenage social life. The John D. and Catherine T. MacArthur Foundation Series on Digital Media and Learning, 2007; 119-142 